\title{
INSTITUTIONAL PRINCIPLES OF FORMATION OF CROSS-BORDER TRANSPORT AND LOGISTICS CLUSTER IN THE CONDITIONS OF DIGITAL AND SUSTAINABLE DEVELOPMENT
}

\author{
Viacheslav Liashenko', Nataliia Trushkina²
}

\begin{abstract}
At the present stage, the strategic vector of transformation of transport and logistics systems in the border regions of Ukraine and the Visegrad Four countries is the integration of transport and logistics infrastructure into a transport and logistics cluster. The purpose of the paper is to substantiate the institutional basis for the formation of a cross-border transport and logistics cluster as an effective form of cooperation between the border regions of Ukraine (Volyn, Zakarpattya and Lviv regions) and the Visegrad Four (Poland, Slovakia, Hungary). Methodology. The theoretical and methodological basis of the study is the provisions of institutional theory, in particular the paradigms of evolutionary development, the theory of clustering, the concepts of strategic and logistical management, enterprise development management. The following general scientific methods were used in the research process: analysis and synthesis, statistical analysis, classification and systems approach, comparison and structural-logical generalization. The article presents the results of analytical assessment of the current state of development of transport and logistics systems of the Visegrad Four. Based on statistical analysis, features, trends, barriers and challenges to the functioning of transport and logistics systems in the border regions of Ukraine have been identified. Results. In order to modernize the regional ecosystems of Ukraine and the Visegrad Four countries, the conceptual provisions for the creation of a cross-border transport and logistics cluster are substantiated. It is proved that this cluster structure should include enterprises in the field of transport and logistics, innovation infrastructure (technology parks, business incubators, industrial parks, etc.), state, regional and local authorities, NGOs, research institutions and centers, higher education institutions that are geographically concentrated in cross-border regions. It is established that for the implementation of the conceptual foundations of the formation of cross-border transport and logistics cluster it is necessary to use a set of mechanisms, which include: regulatory, institutional, organizational and economic, financial, social, informational, environmental. Practical implications. The results of the study can be used to refine the current legal and regulatory framework, namely in amending the Association Agreement between Ukraine and the EU, the Laws of Ukraine "On Cross-Border Cooperation" and "On Principles of State Regional Policy", the State Development Program cross-border cooperation for 2021-2027, Regional Development Strategies of Volyn, Zakarpattya and Lviv regions until 2027 in terms of creating appropriate institutional conditions for the formation of cross-border transport and logistics cluster and determining the mechanism of financial support for its operation. Value/originality. The author's approach to the improvement of legal and institutional support for the development of cross-border cluster structures in Ukraine is formulated, taking into account European practice.
\end{abstract}

Key words: national economy, regional economy, clustering, cluster policy, cluster approach, transport and logistics cluster, organizational form, cross-border cooperation, European practice, institutional principles, legal support, mechanism, sustainable development, digitalization, transformation, smart specialization.

JEL Classification: F15, F20, L22, P51, R40

\footnotetext{
Corresponding author:

${ }^{1}$ Institute of Industrial Economics of the National Academy of Sciences of Ukraine, Ukraine

E-mail: slaval.aenu@gmail.com

ORCID: https://orcid.org/0000-0001-6302-0605

${ }^{2}$ Institute of Industrial Economics of the National Academy of Sciences of Ukraine, Ukraine

E-mail: nata_tru@ukr.net

ORCID: https://orcid.org/0000-0002-6741-7738
} 


\section{Introduction}

In the context of global challenges and external threats facing Ukraine, the formation of partnerships and the deepening of cross-border cooperation is particularly important. Ukraine has a European vector of economic development. At the same time, cross-border cooperation in the field of transport and logistics, which is of strategic importance in ensuring balanced sustainable development of the country, is recognized as a key priority of the national economy and an important object of modern regional policy. The main principles of crossborder cooperation of Ukraine with the Visegrad Four countries are defined by Chapter 27 of the Association Agreement, Laws of Ukraine "On Cross-Border Cooperation" and "On Principles of State Regional Policy", Resolutions of the Cabinet of Ministers of Ukraine "On Approval of the State Strategy for Regional Development 2021-2027" and "On approval of the State program for the development of cross-border cooperation for 2021-2027".

Issues of international cooperation in the transport sector, improvement of mutual and transit transport connections, modernization and development of transport networks are regulated by cooperation agreements, namely: "Agreement between Ukraine and the Republic of Poland on good neighbourliness, friendly relations and cooperation", "Agreements between the Government of Ukraine and the Government of the Slovak Republic on trade, economic and scientific-technical cooperation", "Agreements between the Government of Ukraine and the Government of the Republic of Hungary on economic cooperation".

At the present stage, one of the targets of the national transport strategies of Ukraine and the Visegrad Four countries is integration into the European transport space, increasing the volume of exports of transport services and the realization of transit potential in the system of international transport corridors. To achieve this goal it is necessary to implement and develop a cluster approach to traffic management and the formation of transport and logistics systems that promote innovative development, increase competitiveness and modernize the economy of the regions. At the same time, the strategic vector of transformation of transport and logistics systems in the border regions of Ukraine and the Visegrad
Four countries, which correspond to political, socio-economic, technological, environmental realities, is the integration of transport and logistics infrastructure into a transport and logistics cluster (Kwilinski \& Trushkina, 2019; Trushkina, 2019a; Trushkina, 2019b; Liashenko, Ivanov, Trushkina, 2021; Trushkina, Dzwigol, Kwilinski, 2021; Pushak \& Trushkina, 2021; Liashenko, Osadcha, Trushkina, 2021).

Given this, the purpose of this study is to substantiate the institutional principles for the formation of a cross-border transport and logistics cluster as an effective form of cooperation between the border regions of Ukraine (Volyn, Zakarpattya and Lviv regions) and the Visegrad Four (Poland, Slovakia, Hungary).

\section{Analytical assessment of the current state of development transport and logistics systems of the Visegrad Four}

According to the United Nations Economic Commission for Europe, rail freight in Poland increased by $26.1 \%$ in 2000-2019, and in Hungary by $5.3 \%$. However, the volume of freight transport by rail in Slovakia decreased during this period by $11.6 \%$. Rail freight turnover in Hungary increased by $31.3 \%$, and in Poland - by $1.1 \%$. At the same time, the freight turnover of railway transport in Slovakia decreased by $24.5 \%$ (Table 1).

During 2000-2019, the volume of road freight transport in Poland increased by $39.1 \%$. However, the value of this indicator decreased in Hungary by $22.4 \%$, and in Slovakia - by $0.9 \%$. At the same time, it should be noted that the freight turnover in these countries of the Visegrad Four, on the contrary, has increased. Thus, the freight turnover of road transport in Poland increased 4.8 times, in Hungary - 2.8, and in Slovakia - 2.4 times (Table 2).

According to the analysis of the statistical database of the United Nations Economic Commission for Europe, the volume of river freight transport in Slovakia increased 4 times in 2000-2019, and in Hungary - 1.9 times. But the volume of river freight transport in Poland decreased by $73.4 \%$. During the study period, the turnover of river transport in Poland decreased by $92.8 \%$, in Slovakia - by $32.2 \%$. The value of this indicator in Hungary, on the contrary, increased 2.4 times (Table 3 ). 
Table 1

Dynamics of freight volumes and freight turnover of railway transport in the Visegrad Four countries

\begin{tabular}{|c|c|c|c|c|c|c|}
\hline \multirow{2}{*}{ Years } & \multicolumn{2}{|c}{ Cargo transportation, thousand tons } & \multicolumn{3}{c|}{ Freight turnover, million tkm } \\
\cline { 2 - 7 } & Poland & Slovakia & Hungary & Poland & Slovakia & Hungary \\
\hline 2000 & 185334 & 54177 & 49625 & 54015 & 11234 & 8093 \\
\hline 2005 & 269553 & 49310 & 48706 & 49972 & 9463 & 8530 \\
\hline 2010 & 216767 & 44327 & 45794 & 48705 & 8105 & 8809 \\
\hline 2013 & 232596 & 48401 & 49085 & 50881 & 8494 & 9722 \\
\hline 2014 & 227820 & 50997 & 50593 & 50073 & 8829 & 10158 \\
\hline 2015 & 224320 & 47358 & 50333 & 50603 & 8439 & 10010 \\
\hline 2016 & 222523 & 50727 & 50047 & 50650 & 9111 & 10528 \\
\hline 2017 & 239501 & 47790 & 52682 & 54797 & 8486 & 11053 \\
\hline 2018 & 249260 & 50931 & 52471 & 59388 & 8691 & 10584 \\
\hline 2019 & 233744 & 47869 & 52270 & 54584 & 8480 & 10625 \\
\hline
\end{tabular}

Source: compiled on the basis of information materials from the statistical database of the United Nations Economic Commission for Europe

Table 2

Dynamics of freight volumes and freight turnover of road transport in the Visegrad Four countries

\begin{tabular}{|c|c|c|c|c|c|c|}
\hline \multirow{2}{*}{ Years } & \multicolumn{2}{|c|}{ Cargo transportation, thousand tons } & \multicolumn{3}{c|}{ Freight turnover, million tkm } \\
\cline { 2 - 7 } & Poland & Slovakia & Hungary & Poland & Slovakia & Hungary \\
\hline 2000 & 1083071 & 188901 & 261019 & 72842 & 14340 & 19123 \\
\hline 2005 & 863396 & 195405 & 197727 & 111826 & 22550 & 13243 \\
\hline 2010 & 1216083 & 143244 & 199848 & 202308 & 27575 & 33721 \\
\hline 2013 & 1300608 & 129032 & 169211 & 247594 & 30147 & 35818 \\
\hline 2014 & 1300382 & 142608 & 193112 & 250931 & 31358 & 37517 \\
\hline 2015 & 1264960 & 147225 & 198743 & 260713 & 33525 & 38352 \\
\hline 2016 & 1313657 & 156279 & 197762 & 290749 & 36106 & 40006 \\
\hline 2017 & 1501811 & 176790 & 188259 & 335220 & 35362 & 39687 \\
\hline 2018 & 1390184 & 177222 & 206669 & 315874 & 35590 & 37948 \\
\hline 2019 & 1506450 & 187161 & 202631 & 348952 & 33888 & 36951 \\
\hline
\end{tabular}

Source: compiled on the basis of information materials from the statistical database of the United Nations Economic Commission for Europe

Table 3

Dynamics of freight volumes and freight turnover of river transport in the Visegrad Four countries

\begin{tabular}{|c|c|c|c|c|c|c|}
\hline \multirow{2}{*}{ Years } & \multicolumn{2}{|c|}{ Cargo transportation, thousand tons } & \multicolumn{3}{c|}{ Freight turnover, million tkm } \\
\cline { 2 - 7 } & Poland & Slovakia & Hungary & Poland & Slovakia & Hungary \\
\hline 2000 & 10433 & 1607 & 4422 & 1173 & 1383 & 882 \\
\hline 2005 & 9607 & 2350 & 8413 & 1277 & 88 & 2111 \\
\hline 2010 & 2820 & 10103 & 9952 & 130 & 1189 & 2393 \\
\hline 2013 & 3185 & 8107 & 7857 & 91 & 1006 & 1924 \\
\hline 2014 & 5899 & 7010 & 7825 & 110 & 905 & 1811 \\
\hline 2015 & 4907 & 5721 & 8163 & 83 & 741 & 1824 \\
\hline 2016 & 3821 & 6758 & 8224 & 105 & 903 & 1975 \\
\hline 2017 & 3412 & 6896 & 8414 & 108 & 933 & 1992 \\
\hline 2018 & 2988 & 5567 & 6926 & 119 & 778 & 1608 \\
\hline 2019 & 2779 & 6430 & 8592 & 84 & 937 & 2120 \\
\hline
\end{tabular}

Source: compiled on the basis of information materials from the statistical database of the United Nations Economic Commission for Europe 
It should be noted that the increase in river freight transport is due to the main provisions of the Paris Agreement under the UN Framework Convention on Climate Change to regulate measures to reduce global carbon dioxide emissions. In this regard, the UN is considering ways to reduce the negative impact of freight on nature. One of them, according to the UN Economic Commission for Europe, may be the diversification of inland waterway transport. The United Nations is proposing that the countries of the world (Austria, Hungary, Slovakia, France and Croatia, the share of inland waterway freight is less than 10\%, in Bulgaria, Germany, Romania and Serbia it exceeds $10 \%$, and in the Netherlands is approaching $40 \%$ ) attention to the development of water transport as the most profitable from an economic point of view and safer from an environmental point of view. Modernization of port infrastructure, expansion of the network of freight routes will create new jobs, ensure sustainable development of the transport system in the context of the European Green Course.

The volume of export transactions in trade in goods of Ukraine with Poland increased in $2010-2020$ by $83.3 \%$, and import - by $49.1 \%$. The balance of export-import operations is negative. At the same time, the ratio of imports and exports decreased: if in 2010 the value of this indicator was 1.56 times, in $2020-1.27$ times. The share of exports of goods increased by 3.2 percentage points or from 3.5 to $6.7 \%$ of world foreign trade in goods, and imports - by 3 percentage points or from 4.6 to $7.6 \%$.

Exports of goods from Hungary increased by $47.5 \%$ and imports - by $15.3 \%$. The balance of export-import operations is also negative and decreased by $62 \%$. The ratio of imports to exports decreased: if in 2010 the value of this indicator was 1.42 times, then in $2020-1.11$ times. The share of exports of goods increased by 0.9 percentage points or from 1.7 to $2.6 \%$ of world foreign trade in goods, while imports, by contrast, decreased by 1.7 percentage points or from 2 to $0.3 \%$.

During 2010-2020, the volume of export transactions in trade in goods of Ukraine with Slovakia decreased by $20.8 \%$, and imports - by $161.5 \%$. The balance of export-import operations during this period decreased by $81.8 \%$ : in 2010 it amounted to 126.7 million US dollars, and in 2020 - 696.6 million US dollars. At the same time, in 2010 exports exceeded imports by 1.26 times. And in 2020, imports exceeded exports by 2.56 times. The share of exports of goods decreased by 0.2 percentage points or from 1.1 to $0.9 \%$ of world foreign trade in goods, while imports increased by 1.4 percentage points or from 0.7 to $2.1 \%$ (Table 4 ).

During the period under study, there is a growing trend in the volume of import transactions in foreign trade in services with the Visegrad Four. Thus, the volume of exports in the structure of foreign trade in services of Ukraine with Poland increased in 2020 compared to 2010 by 4.6 times. However, the value of this indicator in Hungary, by contrast, decreased by $12.8 \%$, and in Slovakia - by $9.3 \%$. The volume of imports in the structure of foreign trade in services of Ukraine with Poland increased by $34.9 \%$, in Slovakia - by $30.2 \%$, in Hungary - by $15.9 \%$. The balance of export-import operations in Slovakia and Hungary is positive, but decreased by $31.5 \%$ and $21.6 \%$, respectively. At the same time, the balance of export-import operations in Poland increased 4.5 times: in 2010 it had a negative value, and in 2020 - already positive (Table 5).

According to the State Statistics Service of Ukraine, the volume of exports of transport services of Ukraine with Poland increased in 2020 compared to 2010 by 2.5 times, and with Slovakia - by 1.3 times. The volume of imports of transport services from these countries of the Visegrad Four increased by 2 and 1.7 times. The balance of export-import operations increased 16.6 and 1.2 times, respectively. At the same time, the volume of exports of transport services of Ukraine with Hungary decreased by $42.1 \%$, imports - by $17.5 \%$, and the balance of exportimport operations - by $48.5 \%$ (Table 6).

According to statistical analysis, there is a negative trend in financing the economy of the Visegrad Four countries through direct investment from Ukraine. Thus, the share of direct investment from Ukraine in the Polish economy in 2019 was $0.13 \%$ of the total volume of these investments (in $2010-0.73 \%$ ), and Hungary $-0.26 \%$. And in the development of the Slovak economy does not receive investment (Table 7).

The share of direct investment from Poland in the economy of Ukraine in 2019 was $2.45 \%$ of the European volume of these investments, from Hungary - 1.35\%, from Slovakia - 0.24\% (Table 8). 
Table 4

Geographical structure of foreign trade in goods with the Visegrad Four countries

\begin{tabular}{|c|c|c|c|c|c|c|}
\hline \multirow{2}{*}{ Years } & \multicolumn{3}{|c|}{ Exports, million dollars US } & \multicolumn{3}{c|}{ Imports, million dollars US } \\
\cline { 2 - 7 } & Poland & Slovakia & Hungary & Poland & Slovakia & Hungary \\
\hline 2010 & 1785.6 & 563.9 & 857.0 & 2778.1 & 437.2 & 1213.8 \\
\hline 2011 & 2791.8 & 833.7 & 1327.9 & 3164.2 & 594.3 & 1279.8 \\
\hline 2012 & 2571.0 & 665.2 & 1507.1 & 3545.3 & 580.1 & 1158.6 \\
\hline 2013 & 2547.8 & 752.8 & 1556.9 & 4068.7 & 663.7 & 1400.5 \\
\hline 2014 & 2644.7 & 670.2 & 1509.9 & 3070.8 & 426.9 & 1463.9 \\
\hline 2015 & 1977.3 & 468.5 & 909.7 & 2324.0 & 346.3 & 1608.5 \\
\hline 2016 & 2200.0 & 471.4 & 1053.1 & 2693.3 & 434.9 & 802.0 \\
\hline 2017 & 2724.6 & 656.0 & 1326.4 & 3453.8 & 508.7 & 1152.3 \\
\hline 2018 & 3257.2 & 863.9 & 1646.0 & 3641.9 & 525.9 & 1260.2 \\
\hline 2019 & 3295.8 & 709.6 & 1562.8 & 4109.1 & 651.8 & 1251.1 \\
\hline 2020 & 3272.7 & 446.8 & 1263.8 & 4140.9 & 1143.4 & 1399.5 \\
\hline
\end{tabular}

Source: compiled on the basis of information and analytical materials of the State Statistics Service of Ukraine

Table 5

Geographical structure of foreign trade in services with the Visegrad Four countries

\begin{tabular}{|c|c|c|c|c|c|c|}
\hline \multirow{2}{*}{ Years } & \multicolumn{3}{|c|}{ Exports, million dollars US } & \multicolumn{3}{c|}{ Imports, million dollars US } \\
\cline { 2 - 7 } & Poland & Slovakia & Hungary & Poland & Slovakia & Hungary \\
\hline 2010 & 90.5 & 50.6 & 223.8 & 141.1 & 18.2 & 52.3 \\
\hline 2011 & 132.4 & 49.4 & 83.8 & 142.5 & 33.6 & 101.0 \\
\hline 2012 & 140.3 & 38.0 & 76.5 & 175.4 & 27.6 & 107.9 \\
\hline 2013 & 217.9 & 50.0 & 183.4 & 167.5 & 30.8 & 85.1 \\
\hline 2014 & 202.8 & 41.4 & 98.8 & 148.4 & 46.0 & 65.4 \\
\hline 2015 & 181.9 & 26.8 & 92.3 & 98.7 & 101.8 & 50.0 \\
\hline 2016 & 220.6 & 27.1 & 113.3 & 138.6 & 109.2 & 51.7 \\
\hline 2017 & 296.3 & 40.9 & 147.2 & 150.2 & 108.3 & 35.5 \\
\hline 2020 & 417.9 & 45.9 & 195.1 & 190.3 & 23.7 & 60.6 \\
\hline
\end{tabular}

Source: compiled on the basis of information and analytical materials of the State Statistics Service of Ukraine

Table 6

Export-import operations for the provision of transport services of Ukraine with the Visegrad Four countries

\begin{tabular}{|c|c|c|c|c|}
\hline \multirow{2}{*}{ Country } & \multicolumn{2}{|c|}{ Exports, thousand dollars US } & \multicolumn{2}{c|}{ Imports, thousand dollars US } \\
\cline { 2 - 5 } & 2010 & 2020 & 2010 & 2020 \\
\hline Poland & 48072.5 & 118653.0 & 46510.3 & 92784.6 \\
\hline Slovakia & 28261.2 & 36836.0 & 7773.0 & 12868.8 \\
\hline Hungary & 53623.1 & 31033.1 & 11088.5 & 9147.0 \\
\hline
\end{tabular}

Source: compiled on the basis of information and analytical materials of the State Statistics Service of Ukraine

Thus, in the future it is necessary to pay considerable attention to investing in the development of the economies of Ukraine and the Visegrad Four.

\section{Functioning of transport and logistics systems in the border regions of Ukraine: features, trends, barriers and challenges}

As a rule, railway and road transport are developed in the border regions of Ukraine.
However, according to the analysis of statistical data, the volume of freight transportation by rail in the Zakarpattya region decreased in 2000-2020 by $66.1 \%$; in Lviv - by $44.7 \%$; in Volyn - by $42.5 \%$. The volumes of road freight transport in Lviv oblast decreased by $15.4 \%$, and in Zakarpattya region - by $6.4 \%$. At the same time, the volume of cargo transportation by road in the Volyn region increased by $63.4 \%$ (Table 9). 
Table 7

Dynamics of the volume of direct investments from Ukraine in the economy of the Visegrad Four countries, million dollars US

\begin{tabular}{|c|c|c|c|}
\hline Years & Poland & Slovakia & Hungary \\
\hline 2010 & 47.0 & - & 0.1 \\
\hline 2011 & 46.3 & - & 0.1 \\
\hline 2012 & 52.3 & - & 4.2 \\
\hline 2013 & 56.4 & - & 17.3 \\
\hline 2014 & 53.4 & - & 16.0 \\
\hline 2015 & 50.2 & - & 14.6 \\
\hline 2016 & 48.7 & - & 14.9 \\
\hline 2017 & 6.7 & - & 17.5 \\
\hline 2018 & 6.7 & - & 16.8 \\
\hline 2019 & 8.1 & - & 16.1 \\
\hline
\end{tabular}

Source: compiled on the basis of information and analytical materials of the State Statistics Service of Ukraine
Table 8

Dynamics of the volume of direct investments from the Visegrad Four countries in the economy of Ukraine, million dollars US

\begin{tabular}{|c|c|c|c|}
\hline Years & Poland & Slovakia & Hungary \\
\hline 2010 & 913.0 & 62.1 & 697.6 \\
\hline 2011 & 834.3 & 71.1 & 678.5 \\
\hline 2012 & 897.2 & 70.4 & 684.3 \\
\hline 2013 & 819.8 & 99.7 & 685.9 \\
\hline 2014 & 708.0 & 74.2 & 466.4 \\
\hline 2015 & 679.4 & 72.2 & 333.7 \\
\hline 2016 & 509.1 & 71.1 & 498.1 \\
\hline 2017 & 571.3 & 74.9 & 511.1 \\
\hline 2018 & 631.7 & 66.5 & 565.1 \\
\hline 2019 & 693.7 & 69.1 & 380.7 \\
\hline
\end{tabular}

Source: compiled on the basis of information and analytical materials of the State Statistics Service of Ukraine

Table 9

Dynamics of freight traffic volumes in the border regions of Ukraine

\begin{tabular}{|c|c|c|c|c|c|c|}
\hline \multirow{2}{*}{ Years } & \multicolumn{2}{|c|}{ Volyn region } & \multicolumn{2}{c|}{ Zakarpattya region } & \multicolumn{2}{c|}{ Lviv region } \\
\cline { 2 - 7 } & railway & road & railway & road & railway & road \\
\hline 2000 & 1534.7 & 7581.1 & 3928.4 & 10795.2 & 6168.3 & 29607.0 \\
\hline 2005 & 1787.5 & 10332.3 & 4713.0 & 13702.2 & 6487.0 & 20255.8 \\
\hline 2010 & 1131.1 & 10106.0 & 1710.3 & 11899.2 & 3826.5 & 19456.5 \\
\hline 2013 & 1068.9 & 10358.0 & 1424.1 & 9501.3 & 3223.7 & 21362.1 \\
\hline 2014 & 1017.8 & 10122.6 & 1238.1 & 8934.3 & 3551.0 & 20905.5 \\
\hline 2015 & 1031.5 & 10555.9 & 1703.5 & 9065.5 & 3840.9 & 20581.3 \\
\hline 2016 & 985.6 & 12540.3 & 1245.6 & 9236.6 & 3641.3 & 21511.2 \\
\hline 2017 & 1063.2 & 12955.8 & 1504.8 & 8747.6 & 4005.2 & 23217.9 \\
\hline 2018 & 1124.5 & 13447.2 & 1815.8 & 8751.5 & 3850.4 & 25748.9 \\
\hline 2019 & 1052.0 & 13145.5 & 1605.0 & 9778.4 & 3371.5 & 24390.2 \\
\hline 2020 & 882.1 & 12390.0 & 1332.4 & 10103.2 & 3411.4 & 25038.0 \\
\hline
\end{tabular}

Source: compiled on the basis of information and analytical materials of the Main Department of Statistics in Volyn, Zakarpattya, Lviv regions

During 2000-2020, the freight turnover of road transport in Zakarpattya region increased 10.4 times, in Volyn - 8.9 times, and in Lviv region - 2.9 times (Table 10).

The volume of export transactions in the structure of foreign trade in goods in Lviv region increased in $2010-2020$ by $138.4 \%$, in Volyn region - by $47.9 \%$, in Zakarpattya region - by $16.7 \%$. During this period, the volume of imports increased in Volyn region by $130.2 \%$, in Lviv region - by $69.8 \%$, and in Zakarpattya region, on the contrary, decreased by $6.9 \%$. At the same time, the ratio of imports and exports in the Volyn region has increased: if in 2010 the value of this indicator was 1.31 times, in $2020-2.05$ times.
In the Lviv region there is a tendency to reduce the value of the indicator: in $2010-2.08$ times, and in 2020 - 1.48 times. In 2010, in the Zakarpattya region, imports exceeded exports by 1.17 times, and in 2020, exports exceeded imports by 1.07 times (Table 11 ).

If we consider foreign trade in goods (Table 12) and services (Table 13) between the border regions of Ukraine and the Visegrad Four countries, it should be noted that in the Volyn region there is a negative situation in the organization of export-import operations, as the balance is negative value. And in Lviv and Zakarpattya regions in 2020 the situation has improved and the balance of export-import operations will grow. 
Table 10

Dynamics of freight turnover of road transport in the border regions of Ukraine, million tkm

\begin{tabular}{|c|c|c|c|}
\hline Years & Volyn region & Zakarpattya region & Lviv region \\
\hline 2000 & 321.3 & 423.5 & 1748.8 \\
\hline 2005 & 998.3 & 1755.5 & 3878.0 \\
\hline 2010 & 1690.5 & 2754.3 & 4367.9 \\
\hline 2013 & 1755.2 & 4149.5 & 4564.4 \\
\hline 2014 & 1622.7 & 4410.7 & 4344.8 \\
\hline 2015 & 1838.4 & 4676.1 & 4511.1 \\
\hline 2016 & 2108.6 & 4862.6 & 4604.1 \\
\hline 2017 & 2401.7 & 5285.6 & 5317.6 \\
\hline 2018 & 2770.3 & 5073.1 & 5150.1 \\
\hline 2019 & 2966.5 & 5002.1 & 5127.7 \\
\hline
\end{tabular}

Source: compiled on the basis of information and analytical materials of the Main Department of Statistics in Volyn, Zakarpattya, Lviv regions

Table 11

Regional volumes of foreign trade in goods in the border regions of Ukraine

\begin{tabular}{|c|c|c|c|c|c|c|}
\hline \multirow{2}{*}{ Years } & \multicolumn{3}{|c|}{ Exports, thousand dollars US } & \multicolumn{3}{c|}{ Imports, thousand dollars US } \\
\cline { 2 - 7 } & Volyn region & Zakarpattya region & Lviv region & Volyn region & Zakarpattya region & Lviv region \\
\hline 2010 & 434800.0 & 1156600.0 & 974400.0 & 571500.0 & 1348600.0 & 2028300.0 \\
\hline 2011 & 646350.7 & 1397588.5 & 1201931.1 & 1059592.7 & 1997931.9 & 3202346.9 \\
\hline 2012 & 605783.6 & 1385087.3 & 1343535.6 & 1015138.6 & 2009084.9 & 3373475.2 \\
\hline 2013 & 628811.2 & 1299965.6 & 1290873.7 & 1089007.1 & 2062449.2 & 2655042.5 \\
\hline 2014 & 685422.1 & 1382795.9 & 1305077.7 & 765457.7 & 1734557.0 & 2472001.5 \\
\hline 2015 & 631693.7 & 1094379.6 & 1206324.8 & 622087.5 & 1011507.0 & 1447944.9 \\
\hline 2016 & 611874.2 & 1211902.4 & 1275566.1 & 1130757.2 & 1133380.9 & 1699411.8 \\
\hline 2017 & 689287.7 & 1446423.2 & 1585154.1 & 1334974.0 & 1341735.6 & 2180388.2 \\
\hline 2018 & 719980.9 & 1658975.7 & 1895635.5 & 1368504.4 & 1515819.8 & 2707300.7 \\
\hline 2019 & 694002.3 & 1489957.9 & 2202053.5 & 1455943.0 & 1471227.2 & 3087739.0 \\
\hline 2020 & 642901.2 & 1349544.5 & 2322937.5 & 1315698.3 & 1255371.3 & 3443377.1 \\
\hline
\end{tabular}

Source: compiled on the basis of information and analytical materials of the Main Department of Statistics in Volyn, Zakarpattya, Lviv regions

Table 12

Foreign trade in goods between the border regions of Ukraine and the Visegrad Four countries

\begin{tabular}{|c|c|c|c|c|c|c|}
\hline \multirow{2}{*}{ Country } & \multicolumn{2}{c}{ Volyn region } & \multicolumn{2}{c|}{ Zakarpattya region } & \multicolumn{2}{c|}{ Lviv region } \\
\cline { 2 - 7 } & 2010 & 2020 & 2010 & 2020 & 2010 & 2020 \\
\hline \multicolumn{7}{|c|}{ Exports, thousand dollars US } \\
\hline Poland & 44289.8 & 110856.8 & 48241.5 & 59959.7 & 175489.2 & 654772.2 \\
\hline Slovakia & 9762.3 & 13102.5 & 88612.3 & 37388.9 & 20236.5 & 65502.5 \\
\hline Hungary & 43369.6 & 8467.6 & 672762.5 & 808207.8 & 9860.6 & 158176.8 \\
\hline \multicolumn{7}{|c|}{ Imports, thousand dollars US } \\
\hline Poland & 132880.6 & 209942.0 & 27536.3 & 30770.1 & 608591.7 & 766295.7 \\
\hline Slovakia & 11510.8 & 25695.5 & 43310.6 & 30025.2 & 38407.4 & 52949.7 \\
\hline Hungary & 107566.3 & 127426.1 & 157451.0 & 147251.6 & 45366.6 & 45424.8 \\
\hline \multicolumn{7}{|c|}{ Balance of export-import operations, thousand dollars US } \\
\hline Poland & -88590.8 & -99085.2 & 20705.2 & 29189.6 & -433102.5 & -111523.6 \\
\hline Slovakia & -1748.5 & -12593.0 & 45301.7 & 7363.7 & -18170.9 & 12552.8 \\
\hline Hungary & -64196.7 & -118958.5 & 515311.5 & 660956.2 & -35506.0 & 112752.0 \\
\hline
\end{tabular}

Source: compiled on the basis of information and analytical materials of the State Statistics Service of Ukraine 
During 2010-2019, the share of direct investment in the economy of Lviv region increased by 0.5 percentage points or from 2.62 to $3.12 \%$ of the total volume of these investments; Volyn by 0.38 percentage points or from 0.48 to $0.86 \%$; Zakarpattya region - by 0.2 percentage points or from 0.8 to $1 \%$ (Table 14).

Statistical analysis shows that from the Lviv region there is an insignificant inflow of investments into the economic development of the world. And from Volyn and Zakarpattya regions no investment resources came to the countries of the world (Table 15).

Thus, ensuring balanced sustainable development of the border regions of Ukraine and the Visegrad Four in the context of intensification of integration processes requires the search for qualitatively new tools to increase their competitiveness and investment attractiveness, including the cross-border transport and logistics cluster.

The main mechanism for implementing the development strategies of Ukraine, Poland, Slovakia and Hungary is the clustering mechanism, which involves the development of the concept of regional clusters and a system of measures for financial incentives for cluster initiatives. The concept of clustering of economies is a fundamentally new approach to the territorial organization of ecosystems, which focuses on the links between companies, the presence of clusters of interconnected areas of economic activity.

Table 13

Foreign trade in services between the border regions of Ukraine and the Visegrad Four countries

\begin{tabular}{|c|c|c|c|c|c|c|}
\hline \multirow{2}{*}{ Country } & \multicolumn{2}{c}{ Volyn region } & \multicolumn{2}{c|}{ Zakarpattya region } & \multicolumn{2}{c|}{ Lviv region } \\
\cline { 2 - 7 } & 2010 & 2020 & 2010 & 2020 & 2010 & 2020 \\
\hline \multicolumn{7}{|c|}{ Exports, thousand dollars US } \\
\hline Poland & 4593.3 & 6519.8 & 843.5 & 5964.0 & 11966.7 & 94047.1 \\
\hline Slovakia & 236.6 & 200.0 & 3416.5 & 10331.0 & 112.8 & 2264.4 \\
\hline Hungary & - & 170.6 & 7502.0 & 145523.6 & 245.0 & 3115.7 \\
\hline \multicolumn{7}{|c|}{ Imports, thousand dollars US } \\
\hline Poland & 8035.7 & 7899.4 & 1027.4 & 1009.1 & 13591.3 & 26095.5 \\
\hline Slovakia & 541.9 & 617.3 & 6743.2 & 4116.3 & 726.1 & 634.8 \\
\hline Hungary & - & 17.7 & 5221.6 & 4179.5 & 4775.7 & 2640.3 \\
\hline \multicolumn{7}{|c|}{ Balance of export-import operations, thousand dollars US } \\
\hline Poland & -3442.4 & -1379.6 & -183.9 & 4954.9 & -1624.6 & 67951.6 \\
\hline Slovakia & -305.3 & -417.3 & -3326.7 & 6214.7 & -613.3 & 1629.6 \\
\hline Hungary & - & 152.9 & 2280.4 & 141344.1 & -4530.7 & 475.4 \\
\hline
\end{tabular}

Source: compiled on the basis of information and analytical materials of the State Statistics Service of Ukraine

Table 14

Dynamics of direct investment in the economy of the border regions of Ukraine, million dollars US

\begin{tabular}{|c|c|c|c|}
\hline \multirow{2}{*}{ Years } & \multicolumn{3}{|c|}{ Border regions } \\
\cline { 2 - 4 } & Volyn region & Zakarpattya region & Lviv region \\
\hline 2010 & 218.6 & 364.4 & 1186.8 \\
\hline 2011 & 291.4 & 348.5 & 1300.4 \\
\hline 2012 & 380.5 & 406.4 & 1315.8 \\
\hline 2013 & 341.3 & 437.5 & 1379.5 \\
\hline 2014 & 271.2 & 334.2 & 1097.6 \\
\hline 2015 & 247.1 & 311.8 & 1032.9 \\
\hline 2016 & 246.1 & 317.0 & 833.5 \\
\hline 2017 & 251.3 & 325.1 & 930.0 \\
\hline 2018 & 256.7 & 343.3 & 947.8 \\
\hline 2019 & 306.6 & 360.9 & 1116.3 \\
\hline
\end{tabular}

Source: compiled on the basis of information and analytical materials of the State Statistics Service of Ukraine
Table 15

Dynamics of the volume of direct investments from the border regions of Ukraine in the economy of the world, million dollars US

\begin{tabular}{|c|c|c|c|}
\hline \multirow{2}{*}{ Years } & \multicolumn{3}{|c|}{ Border regions } \\
\cline { 2 - 4 } & Volyn region & Zakarpattya region & Lviv region \\
\hline 2010 & - & - & 0.8 \\
\hline 2011 & - & - & 21.0 \\
\hline 2012 & - & - & 27.4 \\
\hline 2013 & - & - & 43.8 \\
\hline 2014 & - & - & 38.1 \\
\hline 2015 & - & - & 34.5 \\
\hline 2016 & - & - & 15.4 \\
\hline 2017 & - & - & 10.2 \\
\hline 2018 & - & - & 8.8 \\
\hline 2019 & - & - & 8.7 \\
\hline
\end{tabular}

Source: compiled on the basis of information and analytical materials of the State Statistics Service of Ukraine 


\section{Institutional principles of forming a cross-border transport and logistics cluster in the context of cooperation between the border regions of Ukraine and the Visegrad Four}

Legal, economic and organizational principles of cross-border cooperation in Ukraine are regulated by the relevant Law of Ukraine "On Cross-Border Cooperation". But, as the analysis shows, this legislation does not say anything about cluster development and cluster initiatives. It does not refer to cross-border transport and logistics clusters (Table 16).

At present, the State Program for the Development of Cross-Border Cooperation for 2021-2027 has been developed and approved. Among the main obstacles to the effectiveness of cross-border cooperation between Ukraine and the Visegrad Four countries are the development of border transport infrastructure, protection and restoration of ecosystems of the regions, low institutional capacity of entities and participants in cross-border cooperation. This is primarily due to insufficient funding for relevant activities and projects from the state budget.

It should be noted that in this State program insufficient attention is paid to the formation and functioning of cross-border transport and logistics clusters. The document does not provide appropriate mechanisms to ensure their creation and development, the implementation of which will help consolidate the efforts and concentration of resources in the field of transport and logistics to achieve balanced development of border areas and increase the competitiveness of Ukraine.

To date, Regional Development Strategies for 2021-2027 have been developed and Action Plans for their implementation for 2021-2023 have been formed, in which the development of cross-border cooperation is recognized as a strategic priority (Table 17).

In order to intensify cross-border cooperation between the regions of Ukraine and the Visegrad Four, it is advisable to justify and develop a set of conceptual and strategic principles that will contribute to the effective development of cross-border cluster structures.

Among the main stages of developing the Concept of creating a cross-border transport and logistics cluster are the following:

1) analysis and diagnosis of appropriate conditions for the formation (marketing research and analysis of the market of transport and logistics services; assessment of the cluster);

2) development of a cluster formation mechanism (identification of potential cluster members; determination of cluster functioning principles; determination of cluster organizational and legal form; development of regulations and agreements on joint activities; determination of personnel potential of cluster participants);

3) scientific and methodological substantiation and development of the cluster model (formation of the organizational structure of management; determination of the necessary resource provision; development of the mechanism of financial

Table 16

The use of conceptual and categorical apparatus on the clustering of the economy

\begin{tabular}{|l|l|}
\hline \multicolumn{1}{|c|}{ Legislation } & \multicolumn{1}{c|}{ Terminology } \\
\hline $\begin{array}{l}\text { Association Agreement between Ukraine } \\
\text { and the EU }\end{array}$ & $\begin{array}{l}\text { Cluster development (Article 379 of Chapter 10 "Policy in the field of } \\
\text { industry and entrepreneurship"). } \\
\text { Intersectional maritime clusters (Article 411) }\end{array}$ \\
\hline Law of Ukraine "On Cross-Border Cooperation" & $\begin{array}{l}\text { Euroregional cooperation association. } \\
\text { European Grouping of Territorial Cooperation. } \\
\text { Cross-border association }\end{array}$ \\
\hline $\begin{array}{l}\text { Law of Ukraine "On Principles of State Regional } \\
\text { Policy" }\end{array}$ & $\begin{array}{l}\text { Programs and projects for the development of interregional and cross- } \\
\text { border cooperation }\end{array}$ \\
\hline $\begin{array}{l}\text { State strategy of regional development for } \\
2021-2027\end{array}$ & $\begin{array}{l}\text { Cross-border clusters. } \\
\text { World-class regional, interregional and national clusters. } \\
\text { Internationalization of cluster initiatives }\end{array}$ \\
\hline $\begin{array}{l}\text { State program for the development of cross- } \\
\text { border cooperation for } 2021-2027\end{array}$ & Border transport infrastructure \\
\hline $\begin{array}{l}\text { National transport strategy of Ukraine for the } \\
\text { period up to } 2030\end{array}$ & $\begin{array}{l}\text { Network of multimodal transport and logistics clusters. } \\
\text { Logistics centres. }\end{array}$ \\
\hline
\end{tabular}

Source: compiled on the basis of generalization of the current legislative and regulatory framework 
Table 17

Operational development goals by 2027 in part ensuring cross-border cooperation in the regions of Ukraine

\begin{tabular}{|c|c|l|}
\hline $\begin{array}{c}\text { Nevelopment strategy of } \\
\text { Volyn region for the period } \\
\text { until 2027 }\end{array}$ & $\begin{array}{c}\text { Operational goal } \\
\text { Infrastructural support } \\
\text { of cross-border } \\
\text { cooperation }\end{array}$ & $\begin{array}{l}\text { improving the condition of road transport infrastructure and transport } \\
\text { connections of territories; } \\
\text { development of border infrastructure; } \\
\text { implementation of projects for logistics of cross-border cooperation; } \\
\text { development of transit potential }\end{array}$ \\
\hline $\begin{array}{c}\text { Regional development } \\
\text { strategy of Zakarpattya } \\
\text { region for the period } \\
2021-2027\end{array}$ & $\begin{array}{c}\text { Development of } \\
\text { cross-border economic } \\
\text { relations }\end{array}$ & $\begin{array}{l}\text { creation of multidisciplinary international cross-border clusters; } \\
\text { implementation of cluster initiatives with the use of mechanisms such } \\
\text { as "cross-border park and logistics centre" }\end{array}$ \\
$\begin{array}{c}\text { Development strategy of } \\
\text { Lviv region for the period } \\
2021-2027\end{array}$ & $\begin{array}{c}\text { Rogistics, cross-border } \\
\text { and information } \\
\text { and communication } \\
\text { infrastructure }\end{array}$ & $\begin{array}{l}\text { development of cross-border infrastructure (network of logistics } \\
\text { centres in border areas; business border infrastructure and cooperation } \\
\text { between local and regional communities of neighbouring countries); } \\
\text { construction of international checkpoints; } \\
\text { implementation of large infrastructure projects }\end{array}$ \\
\hline
\end{tabular}

Source: compiled on the basis of the generalization of the Strategies of regional development of Volyn, Zakarpattya and Lviv regions for 2021-2027

support; determination of norms and rules of interaction between cluster participants);

4) assessment of the expected synergetic (economic, social, environmental) effect from the creation of a cross-border transport and logistics cluster.

\section{Conclusions}

In order to modernize the regional ecosystems of Ukraine and the Visegrad Four countries, it is advisable to develop a Concept for the creation of a cross-border transport and logistics cluster. To implement it, it is necessary to use a set of mechanisms, the key of which is regulatory.

At present, it is expedient to amend the Association Agreement between Ukraine and the EU, the Laws of Ukraine "On CrossBorder Cooperation" and "On Principles of State Regional Policy", the State Program for Cross-Border Cooperation for 2021-2027, Regional Development Strategies of Volyn and Zakarpattya and Lviv regions by 2027 in terms of creating appropriate institutional conditions for the formation and operation of the crossborder transport and logistics cluster. In addition, the Concept of the National Strategy for the Formation and Development of Cross-Border Clusters should be developed and approved. It is necessary to determine the mechanisms of financial support for their operation, namely: venture investment, crowdfunding, crowdsour- cing, international-private-public partnership based on attracting private investment, credit institutions, foreign investment resources, grants from international financial institutions. The mechanism of international-private-public partnership will allow to successfully plan the development of border transport infrastructure and provide integrated multimodal logistics services; effectively ensure connectivity between different modes of transport and their integration with the territories; to increase the economic potential of transport and logistics infrastructure facilities.

Development and implementation of basic conceptual provisions for the formation of crossborder transport and logistics cluster will create appropriate conditions for increasing the volume and quality of transport and logistics services, gain competitive advantage, strengthen economic partnership, and implement a fundamentally new model of balanced sustainable development of cross-border regions of Ukraine and the Visegrad Four countries, which will meet modern economic requirements.

Further research is planned to summarize the international experience of creation and development of cross-border cluster structures and develop proposals for its application in the regions of Ukraine in terms of economic modernization, smart specialization and digital transformation. 


\section{References:}

Kwilinski, A., \& Trushkina, N. (2019). Logistics cluster as an institution of regional development in the context of economic modernization. Science and practice: collection of scientific articles (June 28, 2019, University of Macedonia) (pp. 55-59). Midas S.A., Thessaloniki, Greece.

Liashenko, V., Ivanov, S., \& Trushkina, N. (2021). A Conceptual Approach to Forming a Transport and Logistics Cluster as a Component of the Region's Innovative Infrastructure (on the Example of Prydniprovsky Economic Region of Ukraine). Virtual Economics, vol. 4, no. 1, pp. 19-53. DOI: https://doi.org/10.34021/ve.2021.04.01(2)

Liashenko, V. I., Osadcha, N. V., \& Trushkina, N. V. (2021). Mozhlyvi orhanizatsiino-pravovi formy transportno-lohistychnoho klasteru v Prychornomorskomu ekonomichnomu raioni [Possible organizational and legal forms of transport and logistics cluster in the Black Sea economic region]. Black Sea Economic Studies, iss. 67, pp. 60-70. DOI: https://doi.org/10.32843/bses.67-10 (in Ukrainian)

Pushak, H. I., \& Trushkina, N. V. (2021). Obgruntuvannia dotsilnosti stvorennia transportnolohistychnoho klasteru $\mathrm{v}$ Karpatskomu ekonomichnomu raioni [Substantiation of Expe-diency of Creation of Transport and Logistics Cluster in the Carpathian Economic Region]. Economic Herald of the Donbas, no. 1(63), pp. 61-77. DOI: https://doi.org/10.12958/1817-3772-2021-1(63)-61-77 (in Ukrainian)

Trushkina, N. (2019a). Financial ensuring mechanism of management innovative development of the transport-logistics system. In M. Bezpartochnyi (Ed.). Organizational-economic mechanism of management innovative development of economic entities: collective monograph (pp. 227-236). Przeworsk: WSSG, vol. 3 .

Trushkina, N. (2019b). Strategic directions of development of regional transport and logistics systems in Ukraine. Proceedings of the 1st International Symposium on Intellectual Economics, Management and Education (September 20, 2019, Vilnius Gediminas Technical University, Vilnius, Lithuania) (pp. 182-183). Bulgaria: Publishing House FABER ltd-Veliko Tarnovo.

Trushkina, N., Dzwigol, H., \& Kwilinski, A. (2021). Cluster Model of Organizing Logistics in the Region (on the Example of the Economic District "Podillya"). Journal of European Economy, vol. 20, no. 1, pp. 127-145. DOI: https://doi.org/10.35774/jee2021.01.127 